\title{
PENGARUH SALINITAS YANG BERBEDA TERHADAP KELULUSHIDUPAN DAN PERTUMBUHAN RAJUNGAN (Portunuspelagicus) PADA STADIA CRAB MUDA
}

\author{
Sri Rejeki, Citra Ayu Furi, Restiana Wisnu Ariyati \\ Departemen Akuakultur, Fakultas Perikanan dan Ilmu Kelautan, Universitas Diponegoro \\ J1. Prof. Soedarto Tembalang, Semarang, Jawa Tengah-50275/Fax. +6224 7474698
}

\begin{abstract}
ABSTRAK
Rajungan (P. pelagicus) merupakan hasil perikanan yang sangat potensial dan menjadi salah satu komoditi ekspor unggulan. Faktor lain yang menjadi kunci kesuksesan dalam budidaya di tambak adalah pengelolaan budidaya selama pelaksanaan di tambak. Hasil pemantauan lingkungan budidaya tambak dapat dijadikan dasar dalam menentukan tindakan yang akan dilaksanakan dalam pengelolaan budidaya tambak. Kualitas air merupakan faktor penentu keberhasilan budidaya di tambak karena komoditas yang dibudidayakan di tambak hidup dalam badan air. Salinitas berhubungan erat dengan osmoregulasi hewan air. Penelitian ini bertujuan untuk mengkaji pengaruh salinitas yang berbeda terhadap kelulushidupan dan pertumbuhan rajungan ( $P$. pelagicus). Penelitian ini dilaksanakan pada bulan Mei 2017 - Juli 2017 di Desa Tambak Bulusan, Kecamatan Karang Tengah, Kabupaten Demak, Jawa Tengah. Hewan uji adalah crab muda rajungan yang berukuran $5 \mathrm{~cm}$. Padat tebar yang digunakan adalah $10 \mathrm{ekor} / \mathrm{m}$. Pakan yang diberikan adalah udang rebon yang diberikan secara fix feeding rate 5\%.Penelitian ini menggunakan metode eksperimen dengan rancangan acak lengkap (RAL) dengan 4 perlakuan dan 3 ulangan. Perlakuan salinitas yang digunakan yaitu 15 ppt, 20 ppt, 25 ppt, dan 30 ppt. Pemeliharaan dilakukan selama 42 hari dan dilakukan pengukuran kualitas air setiap hari. Perbedaan salinitas memberikan pengaruh nyata $(\mathrm{P}<0,05)$ terhadap kelulushidupan, pertumbuhan dan RGR. Hasil penelitian menunjukkan bahwa nilai kelulushidupan rajungan (P. pelagicus) yaitu pada perlakuan D sebesar 83,33 $\pm 5,77 \%$. Pertumbuhan bobot mutlak terbaik yaitu pada perlakuan D sebesar $81,87 \pm 2,42$ g. Laju pertumbuhan relatif rajungan (P. pelagicus) terbaik yaitu pada perlakuan D sebesar $9,11 \pm 0,70 \% /$ hari. Perlakuan terbaik yaitu pada perlakuan D dibandingkan dengan perlakuan A, B dan C.
\end{abstract}

Kata kunci: Kelulushidupan, Pertumbuhan, Rajungan, Salinitas, Osmoregulasi

\begin{abstract}
Blue swimming crab (P. pelagicus) is a potential fishery comodity and has become the leading export. Another factor that becomes the key to success in the cultivation in the pond is the management of cultivation during the implementation in the pond. The results of environmental monitoring of pond farming can be used as a basis in determining the actions to be implemented in the management of pond farming. Water quality is a critical determinant of the success of the cultivation in the ponds because of the commodities cultivated in live ponds in water bodies. Salinity is closely related to the osmoregulation of aquatic animals, in the event of a sudden drop in salinity and within a considerable range. The objectives of this research was to find out the effects of different salinity levels the survival rate and growth of blue swimming crab. This reaserch was conducted in Bulusan village, Karang Tengah districts, Demak district, Central Java start from Mei until July 2017. Theof blue swimming crab with average size of $5 \mathrm{~cm} /$ ind with stocking density was 10 individuals/tank. The feed given was shrimp rebon. This research was conducted by experimental method using Completely Randomized Design with 4 treatments and 3 replications. There were salinity from treatments A with $15 \mathrm{ppt}$, B with 20ppt, C with $25 \mathrm{ppt}$, and D with $30 \mathrm{ppt}$. The maintenance performed for 42 days and water quality monitored daily. The different salinity gave sicnificant effect of survival rate, growth and RGR. The results showed that the best absolute value survival rate of Blue swimming crab (P. pelagicus) that is at treatment $\mathrm{D}$ equal to $83,33 \pm 5,77 \%$. The weight growth value was in treatment $\mathrm{D}$ of $81.87 \pm 2.42 \mathrm{~g}$. The relative growth rate of Blue swimming crab $(\mathrm{P}$. pelagicus) is best at treatment $\mathrm{D}$ equal to $9,11 \pm 0,70 \%$ / day. The best treatment was treatment $\mathrm{D}$ compared to treatments $\mathrm{A}, \mathrm{B}$ and $\mathrm{C}$.
\end{abstract}

Keyword: Survival Rate, Growth, Blue Swimming Crab, Salinity, Osmoregulation

*Corresponding author(email:sri_rejeki7356@yahoo.co.uk) 


\section{PENDAHULUAN}

Salah satu komoditas perikanan yang menjadi andalan ekspor Indonesia adalah rajungan (P. pelagicus). Potensi rajungan yang tumbuh secara alamiah di laut sangat melimpah namun populsai rajungan (P. pelagicus) di alam tersebut semakin terancam dengan rusaknya habitat dan juga eksploitasi oleh nelayan di beberapa daerah karena besarnya permintaan ekspor ke beberapa Negara. Rajungan (P. pelagicus) banyak ditemukan di beberapa perairan lepas pantai dan lautan Indo-pasifik. Di Indonesia rajungan banyak terdapat di daerah mangrove seperti di kabupaten Cilacap, pantai Gilimanuk, pantai Muncar, pantai Pasuruan, Lampung, Medan dan Kalimantan Barat (Susanto, 2007).

$$
\text { Rajungan (P. pelagicus) }
$$
merupakan hasil perikanan yang sangat potensial. Selain memiliki rasa daging yang lezat, nilai gizinya pun cukup tinggi sehingga permintaan akan komoditas ini baik dari pasar lokal maupun pasar ekspor semakin meningkat. Namun, masih sedikit pembudidaya yang berkeinginan membudidayakan rajungan (P. pelagicus). Sulitnya dalam pemeliharaan rajungan (P. pelagicus) dimana SR yang didapat rendah. Salah satu faktor yang menyebabkan SR rajungan (P. pelagicus) rendah adalah kondisi lingkungan yang kurang terkontrol sehingga tidak sesuai dengan habitat aslinya yang menyebabkan rajungan (P. pelagicus) sulit untuk tumbuh. Oleh karena itu, kondisi lingkungan sangat berperan terhadap pertumbuhan dan kelulushidupan rajungan (P. pelagicus). Stadia zoea rajungan bersifat planktonic yang melayang-layang di lepas pantai dan pada fase megalopa berada didekat pantai, setelah mencapai ukuran crab muda rajungan (P. pelagicus) menuju ke estuari. Salinitas merupakan salah satu kualitas air yang berperan dalam kelulushidupan dan pertumbuhan rajungan. Salinitas berhubungan erat dengan osmoregulasi hewan air, apabila terjadi penurunan salinitas secara mendadak dan dalam kisaran yang cukup besar, maka akan menyulitkan hewan dalam pengaturan osmoregulasi tubuhnya sehingga dapat menyebabkan kematian (Anggoro, 2000). Penyebabnya dikarena adanya kontrol dari berbagai proses kimia dan biologi di dalam perairan laut. Kondisi ini menyebabkan sebagian besar organisme yang hidup di perairan laut merupakan organisme yang memiliki toleransi (sensitivitas) terhadap perubahan 
salinitas yang sangat kecil atau organisme yang diklasifikasikan sebagai organisme stenohalin (Widodo dan Suadi, 2006).

Salinitas merupakan salah satu parameter kualitas air yang berperan penting dalam budidaya rajungan ( $\mathrm{P}$. pelagicus). Rajungan (P. pelagicus) pada stadia crab muda adalah stadia yang ideal untuk diterpakan di tambak, karena pada stadia tersebut organ rajungan (P. pelagicus) telah lengkap menyerupai rajungan dewasa. Selain itu, pada stadia crab muda rajungan (P. pelagicus) menurut siklus hidupnya akan kembali ke estuari yang salinitasnya lebih rendah dibandingkan pada stadia zoea dan megalopa, sehingga mampu untuk diaplikasikan pada budidaya di tambak. Faktor lain yang menjadi kunci kesuksesan dalam budidaya di tambak adalah pengelolaan budidaya selama pelaksanaan di tambak. Hasil pemantauan lingkungan budidaya tambak dapat dijadikan dasar dalam menentukan tindakan yang akan dilaksanakan dalam pengelolaan budidaya tambak. Kualitas air merupakan faktor penentu keberhasilan budidaya di tambak karena komoditas yang dibudidayakan di tambak hidup dalam badan air. Kualitas air yang baik salah satunya adalah salinitas yang dibutuhkan untuk dapat mendukung kehidupan rajungan. Apabila salinitas sesuai dan stabil maka rajungan (P. pelagicus) dapat tumbuh dengan baik,namun salinitas tidak sesuai dan tidak stabil maka pertumbuhan rajungan (P. pelagicus) pun akan terhambat.

Penelitian ini bertujuan untuk mengkaji pengaruh salinitas yang berbeda terhadap pertumbuhan dan kelulushidupan rajungan (P. pelagicus). Penelitian ini dilaksanakan pada bulan Mei 2017 - Juli 2017 di Desa Tambak Bulusan, Kecamatan Karang Tengah, Kabupaten Demak, Jawa Tengah.

\section{METODE PENELITIAN}

Hewan uji yang digunakan adalah benih rajungan pada stadia crab muda dengan ukuran $5 \mathrm{~cm}$. Penelitian ini padat penebaran benih rajungan yang digunakan untuk stadia crab muda adalah 10 ekor per wadahnya dengan ukuran per wadahnya $1 \mathrm{~m}^{2}$ (Oniam et al., 2011). Jumlah benih rajungan yang digunakan dalam penelitian ini adalah 120 ekor benih rajungan. Hewan uji yang digunakan berasal dari alam. Pakan yang digunakan selama proses pemeliharaan benih rajungan adalah pakan udang rebon yang telah direbus yang diberikan setiap 3 kali dalam sehari yaitu pagi dan siang dan malam hari.

Alat yang digunakan dalam penelitian selama pemeliharaan dengan salinitas yang berbeda terhadap kelulushidupan dan pertumbuhan benih rajungan (Portunus pelagicus) adalah 
timbangan digital yang digunakan untuk menimbang bobot benih rajungan, jangka sorong yang digunakan untuk mengukur panjang benih rajungan, aerator sebagai penghasil oksigen. Alat lain yang digunakan adalah refraktometer yang digunakan untuk mengukur salinitas, $\mathrm{pH}$ papper digunakan untuk mengukur $\mathrm{pH}$, Do meter digunakan untuk mengukur oksigen terlarut yang terkandung dalam air dan juga termometer yang digunakan untuk mengukur suhu air. Bahan uji yang digunakan adalah air dengan perlakuan salinitas yang berbeda. Masing-masing perlakuan yaitu 15 ppt, 20 ppt, 25 ppt, dan 30 ppt. Perlakuan yang digunakan mengacu pada penelitian sebelumnya oleh Astuti (2008) bahwa untuk media percobaan sesuai perlakuan $(23,28,33,38$ ppt).

Metode yang digunakan dalam penelitian ini adalah metode eksperimental. Metode eksperimental merupakan metode yang menerapkan suatu usaha terencana untuk mengungkapkan fakta-fakta baru atau menguatkan teori dan mengkritik hasil dari penelitian yang sudah ada.Metode ini dimaksudkan untuk mengetahui pengaruh perlakuan salinitas yang berbeda terhadap kelulushidupan dan pertumbuhan benih rajungan.
Rancangan percobaan yang digunakan dalam penelitian ini adalah rancangan acak lengkap (RAL) dengan 4 perlakuan dan 3 kali ulangan. Perlakuan dalam penelitian ini adalah dengan salinitas yang berbeda yaitu:

Perlakuan A : Perlakuan dengan salinitas $15 \mathrm{ppt}$

Perlakuan B : Perlakuan dengan salinitas $20 \mathrm{ppt}$

Perlakuan C : Perlakuan dengan salinitas $25 \mathrm{ppt}$

Perlakuan D : Perlakuan dengan salinitas $30 \mathrm{ppt}$

\section{Pengumpulan data}

Variabel yang diukur meliputi nilai kelulushidupan (SR) bobot mutlak, laju pertumbuhan relatif (RGR) dan kualitas air. Data kualitas air yang diukur meliputi suhu, salinitas, DO dan $\mathrm{pH}$ yang diukur setiap hari, serta amonia di awal dan akhir pengamatan.

\section{Kelulushidupan/ Survival Rate (SR)}

Menurut Effendi (2002), kelulushidupan merupakan prosentase kelulushidupan kultivan yang dapat dihitung dengan rumus sebagai berikut:

$$
S R=\frac{N t}{N o} \times 100 \%
$$




$$
\begin{aligned}
& \text { Dimana: } \quad \mathrm{SR}=\text { kelulushidupan }(\%) \\
& \mathrm{N}_{\mathrm{t}}=\text { jumlah ikan pada akhir } \\
& \mathrm{N}_{\mathrm{o}}=\text { jumlah ikan pada awal }
\end{aligned}
$$

\section{Pertumbuhan}

Menurut

(Effendi,

pertumbuhan bobot rajungan $(\mathrm{P}$. pelagicus) dapat dihitung dengan menggunakan rumus:

$$
\mathrm{W}=\mathrm{Wt}-\mathrm{W} 0
$$

Dimana: $\quad \mathrm{W}=$ laju pertumbuhan relatif $(\mathrm{g})$ $\mathrm{Wt}=$ bobot tubuh rata-rata akhir pemeliharaan $(\mathrm{g})$

$\mathrm{Wo}=$ bobot tubuh rata-rata awal pemeliharaan $(\mathrm{g})$

\section{Laju pertumbuhan relatif}

Laju pertumbuhan relatif (Relative Growth Rate) rajungan dihitung dengan menggunakan rumus RGR bobot (Takeuchi,1988), yaitu :

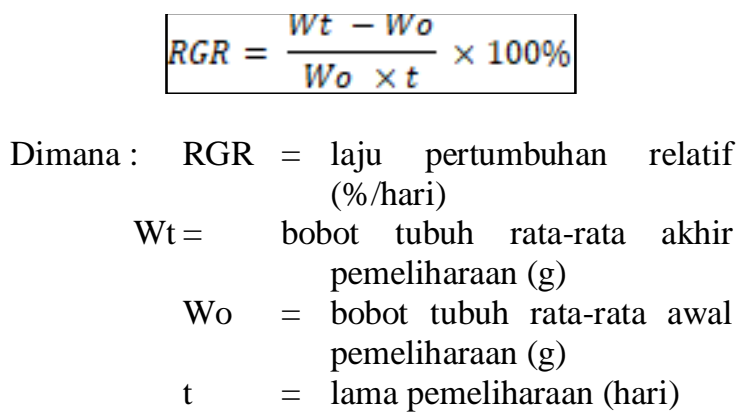

\section{Kualitas Air}

Kualitas air yang diukur pada awal sampai akhir penelitian dengan menggunakanDO meter, refraktometer, $\mathrm{pH}$ papper, termometer. Variabel yang diukur adalah keasaman $(\mathrm{pH})$ air, salinitas, dan oksigen terlarut atau dissolved oxygen/DO (mg/l). Pengukuran kualitas air dilakukan 2 kali dalam sehari yaitu pada pagi hari dan sore hari. Sedangkan untuk pengukuran amonia dilakukan 2 kali selama pemeliharaan yaitu pada awal dan akhir pemeliharaan.

\section{Analisis Data}

Analisa data yang dilakukan meliputi nilai kelulushidupan (SR) bobot mutlak, laju pertumbuhan relatif (RGR) dan kualitas air. Variabel yang didapatkan kemudian dianalisis menggunakan analisis sidik ragam (ANOVA). Analisis ragam dapat dilakukan, jika hasil ketiga uji tersebut menunjukan bahwa data menyebar normal, homogen dan additive. Apabila diketahui terdapat perbedaan yang nyata maka dilakukan uji wilayah ganda Duncan untuk mengetahui perbedaan nilai tengah dari perlakuan, sehingga dapat diperoleh hasil perlakuan yang terbaik (Srigandono, 1981). Data kualitas air dianalisis secara deskriptif.

\section{HASIL DAN PEMBAHASAN}

Hasil

Berdasarkan hasil dari penelitian yang telah dilakukan selama 42 hari pada bulan Mei 2017 sampai Juli 2017 dapat diketahui nilai pertumbuhan bobot, laju pertumbuhan relatif (RGR), dan kelulushidupan (SR). 
Tabel 1. Nilai Rata-rata Pertumbuhan Bobot, Laju Pertumbuhan Relatif (RGR), Kelulushidupan (SR) Rajungan (Portunus pelagicus) Selama Pemeliharaan.

\begin{tabular}{cccc}
\hline \multirow{2}{*}{ Perlakuan } & \multicolumn{3}{c}{ Variabel yang diamati } \\
\cline { 2 - 4 } & Bobot (g) & $\begin{array}{c}\text { RGR } \\
(\% / \text { hari })\end{array}$ & SR (\%) \\
\hline A & $58,81 \pm 1,88^{\mathrm{d}}$ & $6,54 \pm 0,22^{\mathrm{c}}$ & $46,67 \pm 5,77^{\mathrm{c}}$ \\
B & $69,06 \pm 0,77^{\mathrm{c}}$ & $7,68 \pm 0,22^{\mathrm{b}}$ & $60,00 \pm 10,00^{\mathrm{b}}$ \\
C & $73,06 \pm 1,97^{\mathrm{b}}$ & $8,11 \pm 0,48^{\mathrm{b}}$ & $73,33 \pm 10,00^{\mathrm{ab}}$ \\
D & $81,87 \pm 2,42^{\mathrm{a}}$ & $9,11 \pm 0,70^{\mathrm{a}}$ & $83,33 \pm 5,77^{\mathrm{a}}$ \\
\hline
\end{tabular}

Hasil penelitian pengaruh salinitas yang berbeda pada variable yang diamati yaitu bobot mutlak, laju pertumbuhan relatif dan kelulushidupan rajungan $(\mathrm{P}$ pelagicus). Berdasarkan data nilai pertumbuhan bobot, RGR, dan SR Rajungan (Portunus pelagicus) selama pemeliharaan dapat diketahui pengaruh salinitas yang berbeda terhadap pertumbuhan dan kelulushidupan dengan menggunakan analisis ragam dan uji duncan. Analisis ragam dan uji duncan nilai kelulushidupan (SR), pertumbuhan bobot, laju pertumbuhan relatif (RGR) dan kualitas air.

\section{a. Kelulushidupan (SR)}

Kelulushidupan (SR) tersebut telah dilakukan uji normalitas, uji homogenitas, dan uji additivitas. Menurut data yang didapatkan menunjukkan bahwa ragam data tersebut menyebar normal, bersifat homogen, dan additive sehingga telah memenuhi syarat untuk dilakukan uji analisis ragam. Hasil analisis ragam Kelulushidupan (SR) rajungan (P. pelagicus) tersaji pada Tabel 2.

Berdasarkan hasil analisis ragam data kelulushidupan (SR) rajungan (P. pelagicus) menunjukkan bahwa perbedaan salinitas berpengaruh nyata dengan nilai Fhitung $>$ Ftabel. Perbedaan pengaruh perlakuan dengan perlakuan lain dapat diketahui dengan uji DUNCAN. Adapun untuk hasil uji DUNCAN terhadap kelulushidupan (SR) rajungan (P. pelagicus) tersaji pada Tabel 3.

Tabel 2. Analisis Ragam (ANOVA) Kelulushidupan (SR) Rajungan (P. pelagicus) pada Stadia Crab Muda dengan Perlakuan Salinitas yang Berbeda.

\begin{tabular}{cccccc}
\hline SK & DB & JK & KT & Fit & Ftab \\
\hline Perlakuan & 3,00 & 2291,67 & 763,89 & 15,28 & 4,07 \\
Galat & 8,00 & 400,00 & 50,00 & & \\
Total & 11,00 & 2691,67 & & & \\
\hline
\end{tabular}

Keterangan:

$*=\mathrm{F}_{\text {hitung }}>\mathrm{F}_{\text {tabel }}=$ berpengaruh nyata $(\mathrm{P}<0,05)$.

Tabel 3. Uji Wilayah Ganda Duncan Nilai kelulushidupan Rajungan (P. pelagicus) pada Stadia Crab Muda Dengan Perlakuan Salinitas yang Berbeda.

\begin{tabular}{cccccc}
\hline $\begin{array}{c}\text { Perla- } \\
\text { kuan }\end{array}$ & $\begin{array}{c}\text { Nilai } \\
\text { Tengah }\end{array}$ & Selisih & & & \\
\hline D & 83,33 & D & & & \\
C & 73,33 & 10,00 & C & & \\
B & 60,00 & $13,33^{*}$ & 13,33 & B & \\
A & 46,67 & $13,33^{*}$ & $26,66^{*}$ & 13,33 & A \\
\hline
\end{tabular}

Keterangan: 
$\mathrm{A}=$ perlakuan dengan salinitas $15 \mathrm{ppt}$

$\mathrm{B}=$ perlakuan dengan salinitas $20 \mathrm{ppt}$

$\mathrm{C}=$ perlakuan dengan salinitas $25 \mathrm{ppt}$

$\mathrm{D}=$ perlakuan dengan salinitas $30 \mathrm{ppt}$

* =Berbeda nyata $(\mathrm{P}<0,05)$

\section{b. Pertumbuhan bobot mutlak}

Pertumbuhan bobot mutlak tersebut telah dilakukan uji normalitas, uji homogenitas, dan uji additivitas. Menurut data yang didapatkan menunjukkan bahwa ragam data tersebut menyebar normal, bersifat homogen, dan additive sehingga telah memenuhi syarat untuk dilakukan uji analisis ragam. Hasil analisis ragam pertumbuhan bobot mutlak rajungan ( $P$. pelagicus) tersaji pada Tabel 4.

Berdasarkan hasil analisis ragam data pertumbuhan bobot mutlak rajungan (P. pelagicus) menunjukkan bahwa perbedaan salinitas berpengaruh nyata dengan nilai Fhitung>Ftabel. Perbedaan pengaruh perlakuan dengan perlakuan lain dapat diketahui dengan uji DUNCAN. Adapun untuk hasil uji DUNCAN terhadap pertumbuhan bobot rajungan (P. pelagicus) tersaji pada Tabel 4:

Tabel 4. Analisis Ragam Pertumbuhan Bobot Rajungan ( $\mathrm{P}$. pelagicus) Pada Stadia Crab Muda Dengan Perlakuan Salinitas Yang Berbeda.

\begin{tabular}{cccccc}
\hline SK & DB & JK & KT & Fit & Ftab \\
\cline { 5 - 6 } & & & & & $\mathbf{0 , 0 5}$ \\
\hline Perlakuan & 3,00 & 822,98 & 274,33 & $79,33 *$ & 4,07 \\
Eror & 8,00 & 27,67 & 3,46 & & \\
Total & 11,00 & 850,64 & & & \\
\hline
\end{tabular}

Keterangan:

$*=\mathrm{F}_{\text {hitung }}>\mathrm{F}_{\text {tabel }}=$ berpengaruh nyata $(\mathrm{P}<0,05)$

Tabel 5. Uji Wilayah Ganda Duncan Nilai Pertumbuhan Bobot Mutlak (G) Rajungan (P. Pelagicus) pada Stadia Crab Muda Dengan Perlakuan Salinitas yang Berbeda.

\begin{tabular}{cccccc}
\hline $\begin{array}{c}\text { Perla- } \\
\text { kuan }\end{array}$ & $\begin{array}{c}\text { Nilai } \\
\text { Tengah }\end{array}$ & Selisih & & & \\
\hline D & 81,87 & D & & & \\
C & 73,06 & $8,81^{*}$ & C & & \\
B & 69,06 & $12,81^{*}$ & $4,00^{*}$ & B & \\
A & 58,81 & $23,06^{*}$ & $14,25^{*}$ & $10,25^{*}$ & A
\end{tabular}

Keterangan:

$\mathrm{A}=$ perlakuan dengan salinitas $15 \mathrm{ppt}$

$\mathrm{B}=$ perlakuan dengan salinitas $20 \mathrm{ppt}$

$\mathrm{C}=$ perlakuan dengan salinitas $25 \mathrm{ppt}$

$\mathrm{D}=$ perlakuan dengan salinitas $30 \mathrm{ppt}$

* =Berbeda nyata $(\mathrm{P}<0,05)$

\section{c. Laju pertumbuhan relatif (RGR)}

Laju pertumbuhan relatif (RGR) tersebut telah dilakukan uji normalitas, uji homogenitas, dan uji additivitas. Menurut data yang didapatkan menunjukkan bahwa ragam data tersebut menyebar normal, bersifat homogen, dan additive sehingga telah memenuhi syarat untuk dilakukan uji analisis ragam. Hasil analisis ragam laju pertumbuhan relatif rajungan $(\mathrm{P}$. pelagicus) tersaji pada Tabel 6.

Berdasarkan hasil analisis ragam data laju pertumbuhan relatif rajungan $(\mathrm{P}$. pelagicus) menunjukkan bahwa perbedaan salinitas berpengaruh nyata dengan nilai Fhitung $>$ Ftabel. Perbedaan pengaruh perlakuan dengan perlakuan lain dapat diketahui dengan uji DUNCAN. Adapun untuk hasil uji DUNCAN terhadap laju 
pertumbuhan relatif rajungan $(\mathrm{P}$ pelagicus) tersaji pada Tabel 7.

Tabel 6. Analisis Ragam Laju Pertumbuhan Relatif Rajungan (P. pelagicus) pada Stadia Crab Muda Dengan Perlakuan Salinitas yang Berbeda.

\begin{tabular}{cccccc}
\hline SK & DB & JK & KT & Fit & Ftab \\
\hline Perlakuan & 3,00 & 10,26 & 3,42 & $16,84^{*}$ & 4,07 \\
Galat & 8,00 & 1,63 & 0,20 & & \\
Total & 11,00 & 11,88 & & & \\
\hline
\end{tabular}

Keterangan:

$*=\mathrm{F}_{\text {hitung }}>\mathrm{F}_{\text {tabel }}=$ berpengaruh nyata $(\mathrm{P}<0,05)$

Tabel 7. Uji Wilayah Ganda Duncan Nilai Laju Pertumbuhan Relatif Rajungan (P. pelagicus) pada Stadia Crab Muda Dengan Perlakuan Salinitas yang Berbeda.

\begin{tabular}{cccccc}
\hline $\begin{array}{c}\text { Perla- } \\
\text { kuan }\end{array}$ & $\begin{array}{c}\text { Nilai } \\
\text { Tengah }\end{array}$ & Selisih & & & \\
\hline D & 9,11 & D & & & \\
C & 8,11 & $1,00^{*}$ & C & & \\
B & 7,68 & $1,43^{*}$ & 0,43 & B & \\
A & 6,54 & $2,57^{*}$ & $1,57^{*}$ & $1,14^{*}$ & A \\
\hline
\end{tabular}

Keterangan:

$\mathrm{A}=$ perlakuan dengan salinitas $15 \mathrm{ppt}$

$\mathrm{B}=$ perlakuan dengan salinitas $20 \mathrm{ppt}$

$\mathrm{C}=$ perlakuan dengan salinitas $25 \mathrm{ppt}$

$\mathrm{D}=$ perlakuan dengan salinitas $30 \mathrm{ppt}$

* = Berbeda nyata $(\mathrm{P}<0,05)$

\section{d. Kualitas air}

Pengelolaan kualitas air media pemeliharaan sangatlah penting untuk diperhatikan karena mempengaruhi keberhasilan dalam pemeliharaan atau budidaya rajungan. Kualitas air memiliki pengaruh terhadap keseimbangan fisiologis dari tubuh rajungan (P. pelagicus). Kualitas air yang tidak sesuai dapat menyebabkan kesehatan rajungan (P. pelagicus) terganggu bahkan menyebabkan stres dan bisa mengakibatkan penyakit bahkan kematian pada rajungan (P. pelagicus). Hasil pengukuran parameter kualitas air pada media pemeliharaan rajungan $(\mathrm{P}$. pelagicus) selama pemeliharaan tersaji pada Tabel 8.

Tabel 8. Hasil Pengukuran Parameter Kualitas Air pada Media Pemeliharaan Rajungan (P. pelagicus)Selama Penelitian.

\begin{tabular}{cccccc}
\hline $\begin{array}{c}\text { Parame } \\
\text { ter }\end{array}$ & A & B & $\begin{array}{c}\text { Perla } \\
\text { kuan }\end{array}$ & $\begin{array}{c}\text { Kela- } \\
\text { yakan }\end{array}$ \\
\hline & $27-$ & $26,9-$ & $27-$ & $27-$ & $27-$ \\
\hline $\begin{array}{c}\text { Suhu } \\
\left({ }^{0} \mathrm{c}\right)\end{array}$ & 29 & 30 & 29,6 & 29,4 & $31,0^{\mathrm{a}}$ \\
$\begin{array}{c}\text { Salinitas } \\
(\mathrm{ppt})\end{array}$ & 15 & 20 & 25 & 30 & $20-36^{\mathrm{b}}$ \\
& $7,7-$ & $8,02-$ & $7,89-$ & 7,76 & $7,2-$ \\
pH & 8,34 & 8,46 & 8,36 & - & $8,6^{\mathrm{a}}$ \\
& & & & 8,15 & \\
Oksigen & $4,10-$ & $4,12-$ & $4,19-$ & 4,16 & \\
Terlarut & 5,53 & 5,58 & 5,40 & $-5,6$ & $4,-6^{\mathrm{c}}$ \\
$(\mathrm{mg} / \mathrm{l})$ & 0,07 & $0,076 /$ & $0,078 /$ & 0,07 & \\
Amonia & $7 / 0,0$ & 0,092 & 0,096 & $6 / 0$, & $<0,1^{\mathrm{d}}$ \\
$(\mathrm{mg} / \mathrm{l})$ & 89 & & & 097 & \\
\hline
\end{tabular}

Keterangan: (a) Astuti (2008)

(b) Susanto et al., (2014)

(c) Adi (2011)

(d) Yasin (2011)

\section{Pembahasan}

Kelulushidupan merupakan suatu nilai perbandingan antara jumlah organisme awal saat penebaran yang dinyatakan dalam bentuk persen dimana semakin besar nilai persentase menunjukkan semakin banyak organisme yang hidup selama pemeliharaan. Kelulushidupan merupakan parameter keberhasilan suatu kegiatan budidaya.

Kelulushidupan merupakan suatu nilai perbandingan antara jumlah 
organisme awal saat penebaran yang dinyatakan dalam bentuk persen dimana semakin besar nilai persentase menunjukan semakin banyak organisme yang hidup selama pemeliharaan (Effendi, 2002).

Berdasarkan hasil analisis ragam menunjukkan bahwa perbedaan salinitas rajungan (P. pelagicus) berpengaruh nyata terhadap tingkat kelulushidupan. Nilai rata-rata tingkat kelulushidupan tertinggi adalah pada perlakuan D sebesar 83,33\%, perlakuan C sebesar $73,33 \%$, perlakuan B sebesar $66,67 \%$ dan tinkat kelulushidupan terendah yaitu pada perlakuan A sebesar 46,67\%. Pada perlakuan A tingkat kelulushidupan rendah dibawah 50\% diduga akibat penanganan selama penelitian mengalami stress, ditandai dengan hilangnya nafsu makan, pergerakan lambat. Selain itu, rendahnya salinitas yang awalnya berkisar 35 ppt di laut menjadi 15 ppt. Walaupun rajungan (P. pelagicus) bersifat osmoregulasi atau mampu mentolerir salinitas tertentu, namun perbedaan salinitas yang cukup jauh mengakibatkan rajungan $(P$. pelagicus) tersebut stress. Hal ini diduga sesuai dengan habitat alaminya, dalam hal ini pada stadia tersebut rajungan sudah melakukan migrasi ke arah estuari (pantai) yang salinitasnya lebih rendah dari laut lepas (Astuti, 2008).

Tingginya mortalitas terutama pada saat moulting rajungan (P. pelagicus) sangat lemah, diduga karena adanya pengaruh salinitas yang berbeda dimana apabila salinitas terlalu rendah menyebabkan tekanan osmotik media mendekati isoosmotik sehingga pemanfaatan energi untuk osmoregulasi sedikit dan porsi energi untuk pertumbuhan udang lebih banyak (Hamzah 2002). Pertumbuhan bersifat diskontinyu yang terjadi hanya setelah ganti kulit yaitu saat kulit luarnya belum mengeras sempurna. Proses ganti kulit terjadi kalsifikasi yaitu proses penyerapan kalsium secara osmotik dari lingkungan. keberadaan ion kalium berkaitan dengan aktivitas enzim $\mathrm{Na}+\mathrm{K}+\mathrm{ATPase}$ dan dengan adanya penurunan salinitas pada media akan meningkatkan mekanisme osmoregulasi. Kalium termasuk dalam logam esensial yang diperlukan dalam proses fisiologis hewan yang biasanya terikat dalam protein termasuk enzim yang berguna dalam proses metabolisme tubuh (Taqwa et al., 2012). Sifat osmotik air berasal dari seluruh elektrolit yang larut dalam air tersebut di mana semakin tinggi salinitas maka konsentrasi elektrolit makin besar sehingga tekanan osmotiknya makin tinggi (Pamungkas, 2012). Perubahan nilai kualitas air seperti suhu, salinitas, DO dan $\mathrm{pH}$ yang drastis dapat mempengaruhi fisiologis dan tingkat reproduksi pada rajungan sehingga membuat rajungan 
stress dan stress dapat menyebabkan kematian.

Selain salinitas kematian rajungan (P. pelagicus) juga bisa disebabkan oleh tingkat kekebalan tubuh atau system imun, apabila system imun rajungan baik maka stress akan dapat dikurangi. Namun, apabila sistem imun pada rajungan (P. pelagicus) kurang baik maka menyebabkan mudah stress dan mengalami kematian. Menurut Wahyu (2012), menyatakan bahwa faktor yang berpengaruh terhadap aktivitas metabolisme adalah faktor internal dan eksternal. Faktor internal yaitu hormon, parasit, infeksi penyakit, agen stress, dan status fisiologi dari hewan terkait dengan genetik, umur, reproduksi, dan sebagainya. Faktor eksternal yang penting antara lain pakan (untuk semua hewan), suhu, konsentrasi oksigen, salinitas, dan turbiditas.

Pengaruh perlakuan salinitas yang berbeda terhadap pertumbuhan rajungan menunjukkan pertambahan bobot yang signifikan pada setiap perlakuan. Hal ini dapat dilihat dari adanya perbedaan berat dari rajungan (P. pelagicus). Berdasarkan hasil pengamatan, rajungan (P. pelagicus) yang memiliki nilai penambahan bobot yang paling efektif dari yang tertinggi sampai terendah terdapat pada perlakuan D

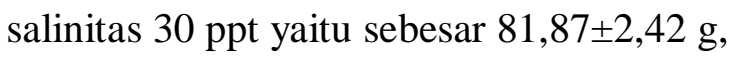
perlakuan $\mathrm{C}$ salinitas $25 \mathrm{ppt}$ sebesar $73,06 \pm 1,97 \mathrm{~g}$, perlakuan B salinitas $20 \mathrm{ppt}$ sebesar 69,06 $\pm 0,77$, dan perlakuan A

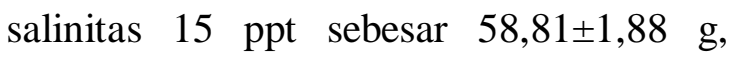
sehingga, dapat dikatakan bahwa pada perlakuan D dengan salinitas 30 ppt yaitu sebesar $81,87 \pm 2,42$ g. Hal ini diduga karena pada perlakuan D sesuai dengan habitat asli rajungan (P. pelagicus) tersebut sehingga proses pertumbuhan dapat berjalan dengan baik. Hal ini terbukti dari adanya perubahan pertumbuhan rajungan (P. pelagicus) yang ditandai dengan bertambahnya bobot, panjang dan adanya molting. Menurut Fatmawati (2009) menyatakan bahwa pertumbuhan pada rajungan adalah perubahan ukuran, dapat berupa panjang atau berat dalam waktu tertentu setelah molting. Pertumbuhan dipengaruhi oleh faktor jumlah dan ukuran makanan yang tersedia, suhu, oksigen terlarut, kualitas air, umur dan ukuran organisme.

Berdasarkan dari hasil analisis ragam untuk pertumbuhan bobot rajungan (P. pelagicus) menujukkan bahwa perlakuan dengan salinitas yang berbeda memberikan pengaruh nyata $(\mathrm{P}<0,05)$. Bobot terendah sampai tertinggi terjadi 
pada perlakuan A dengan salinitas $15 \mathrm{ppt}$, perlakuan B dengan salinitas $20 \mathrm{ppt}$, perlakuan $\mathrm{C}$ dengan salinitas $25 \mathrm{ppt}$, dan perlakuan D dengan salinitas 30 ppt. Hal ini diduga karena ada kaitannya dengan siklus hidupnya. Menurut Jafar (2011), menyatakan bahwa habitat rajungan adalah pada pantai bersubstrat pasir, pasir berlumpur dan di pulau berkarang, juga berenang dari dekat permukaan laut (sekitar $1 \mathrm{~m}$ ) sampai kedalaman 65 meter. Rajungan hidup di daerah estuaria kemudian bermigrasi ke perairan yang bersalinitas lebih tinggi untuk menetaskan telurnya, dan setelah mencapai rajungan muda akan kembali ke estuaria.

Pertumbuhan merupakan salah satu faktor penting dalam perkembangan rajungan (P. pelagicus) dimana dapat dilihat dari penambahan berat, panjang dan lebar dari rajungan (P. pelagicus) tersebut. Dengan demikian, rajungan (P. pelagicus) dapat melakukan molting. Penelitian yang dilakukan selama 42 hari ini rajungan (P. pelagicus) mengalami molting. Menurut Fujaya et al. (2013), siklus molting terdiri atas molt, postmolt, intermolt, dan premolt. Fase molt merujuk ke proses ecdysis, yakni pelepasan eksoskeleton yang keras. Fase setelah ecdysis disebut post molt, yakni fase dimana eksoskeleton masih lunak, penyerapan air merentangkan eksoskeleton yang baru sehingga ukuran hewan menjadi lebih besar. Selanjutnya terjadi mineralisasi dan pengerasan eksoskeleton. Periode intermolt atau anecdysis adalah periode non aktif dan merupakan periode terlama dari siklus molting. Selama waktu ini, terjadi regenerasi otot, penyimpanan energi dalam bentuk glycogen dan lipid diakumulasikan dalam hemolimph dan midgut untuk mensukseskan ecdysis berikutnya. Premolt, atau proecdysis adalah fase dimana terjadi atrophy otot somatic, resorption eksoskeleton lama dan pembentukan eksoskeleton baru sebagai persiapan untuk dimulainya ecdysis.

Pengaruh salinitasyang berbedapada setiap perlakuan menunjukkan hasil yang cukup signifikan pada tiap perlakuannya. Berdasarkan hasil pengamatan selama 42 hari pengamatan dapat diketahui bahwa rajungan (P. pelagicus) yang memiliki nilai laju pertumbuhan relatif dari yang terendah sampai tertinggi yaitu pada perlakuan A sebesar 6,54 $\pm 0,22 \%$ /hari, perlakuan B sebesar 7,68 $\pm 0,22 \%$ /hari, perlakuan C sebesar $8,11 \pm 0,48 \%$ /hari dan pada perlakuan D sebesar 9,11 $\pm 0,70$ \%/hari. Perlakuan D dengan salinitas paling tinggi mendapatkan nilai laju pertumbuhan relative bobot yang lebih tinggi dibandingkan dengan perlakuan $\mathrm{C}$, perlakuan B dan perlakuan A. Hal ini dikarenakan salinitas berperan penting dalam proses laju pertumbuhan relatif rajungan (P. pelagicus). Menurut Wahyu 
(2012), menyatakan bahwa pertumbuhan relatif pada salinitas yang berbeda merefleksikan kebutuhan energi untuk osmoregulasi pada berbagai salinitas yang tergantung pada besarnya pengaruh non osmoregulasi pada metabolisme. Kebutuhan energi untuk pemeliharaan dan aktivitas harus terpenuhi sebelum nantinya pertumbuhan dapat terjadi. Tingkat pemberian pakan harus mencukupi untuk kebutuhan energi.

Selain faktor lingkungan seperti kualitas air, pakan juga mempengaruhi laju pertumbuhan relatif. Selama pemeliharaan selama 42 hari rajungan (P. pelagicus) diberi pakan sebanyak 5\% dari bobot biomasa yaitu pada pagi hari pukul 06:00 WIB, siang hari pada pukul 13:00 WIB dan pada malam hari pukul 20:00 WIB. Pakan yang digunakan untuk stadia crablet yaitu berupa udang rebon yang dipanaskan terlebih dahulu untuk menghindari adanya bau yang tidak diinginkan pada bak perlakuan. Menurut Erlinda et al., ( 2015) menyatakan bahwa rajungan (P. pelagicus) memakan beragam jenis makanan yang dapat dibagi menjadi 4 kategori/kelompok yaitu: plankton, moluska \& crustacea, daging, dan material tidak teridentifikasi (MTT). Setelah menjadi dewasa rajungan memakan daging dan makanan yang telah ditangkap dan dihancurkan oleh capitnya akan segera dimasukkan ke dalam mulut.

Pengelolaan kualitas air media pemeliharaan sangatlah penting untuk diperhatikan karena mempengaruhi keberhasilan dalam peeliharaan atau budidaya rajungan (P. pelagicus). Kualitas air memiliki pengaruh terhadap keseimbangan fisiologis dari tubuh rajungan (P. pelagicus). Kualitas air yang tidak sesuai dapat menyebabkan kesehatan rajungan (P. pelagicus) terganggu bahkan menyebabkan stres dan bisa mengakibatkan penyakit bahkan kematian pada rajungan (P. pelagicus).

Berdasarkan pengukuran kualitas air yang telah dilakukan yaitu pengukuran suhu, salinitas, $\mathrm{pH}$ dan DO setiap hari yaitu dilakukan pada pagi hari dan sore hari. Sedangkan, untuk pengukuran ammonia dilakukan pada awal pemeliharaan dan akhir pemeliharaan. Berdasarkan penelitian ini didapatkan hasil bahwa suhu air pada pemeliharaan rajungan (P. pelagicus) pada stadia crab muda ini berkisar $27^{\circ} \mathrm{C}$ sampai $30^{\circ} \mathrm{c}$. Suhu dapat dikatakan stabil dikarenakan masih dalam lingkup yang terkontrol. Meskipun terdapat dalam ruang semi terbuka namun pada area pinggir ditutup dengan terpal sehingga kondisi air pada setiap perlakuan 
lebih terkontrol. Hal ini memperlihatkan bahwa kondisi suhu perairan tempat pemeliharaan telah sesuai dan mendukung kehidupan rajungan (P. pelagicus) yang bersifat euritermal, yakni mempunyai kemampuan beradaptasi pada media yang kisaran suhunya cukup luas. Astuti (2008), menyatakan bahwa kisaran suhu yang baik untuk budidaya rajungan adalah antara 27 ${ }^{\circ} \mathrm{c}$ sampai $31^{\circ} \mathrm{c}$.

Berdasarkan penelitian ini didapatkan hasil bahwa salinitas air pada pemeliharaan rajungan ( $\mathrm{P}$. pelagicus) pada stadia crab muda ini berbeda tiap perlakuannya. Pada perlakuan A salinitas $15 \mathrm{ppt}$, perlakuan B salinitas 20 ppt, perlakuan C salinitas 25 ppt dan perlakuan D salinitas 30 ppt. Hal ini dikarenakan rajungan (P. pelagicus) adalah salah satu hewan yang mampu ber osmoregulasi. Osmoregulasi sendiri merupakan suatu upaya atau kemampuan untuk mengontrol keseimbangan air dan ion antara didalam tubuh dan lingkungannya. Melalui pengaturan tekanan osmosis.

Krustace jenis kepiting yang hidup dipantai mempunyai toleransi yang kecil untuk air tawar tetapi mempertahankan konsentrasi ion yang tinggi di perairan estuary. Dalam mengatur osmoregulasi pada golongan krustace terdapat organ yang berperan. Menurut Lantu (2010), insang untuk golongan eurihalin krustace berperan sebagai organ utama dalam pengaturan ion untuk proses osmoregulasi. Meskipun terdapat variasi secara morfologi, insang serta bagian-bagiannya memiliki bentuk sel yang menggambarkan kemampuan untuk transpor ion-ion. Karakteristik yang khusus dari sel ephotel dilengkapi dengan bentuk permukaan membrane, terutama di bagian basolateral yang bersentuhan langsung dengan cairan. Mitokondria dari sel-sel ini menyediakan ATP serta fosagen yang menjadi energi untuk transpor ion. Sel epitel insang yang berfungsi dalam pertukanan gas bentuknya lebih tipis. Dua macam enzim yang membantu transpor ion melewati insang krustace adalah karbonat anhydrase dan arginine kinase. Karbonat anhydrase menyediakan ion $\mathrm{H}^{+}$dan $\mathrm{HCO}_{3}{ }^{-}$sebagai lawan ion $\mathrm{Na}^{+}$dan $\mathrm{CI}^{-}$untuk pertukaran dengan mengkatalisis hidrasi $\mathrm{CO}_{2}$ di dalam se linsang. Aktifitas dari karbonat anhidrase dalam sitoplasma insang akan bertambah secara drastic ketika kepiting berpindah dari tempat yang bersalinitas tinggi ke tempat yang bersalinitas rendah, dimana fungsi menyediakan ion yang akan melawan ion $\mathrm{NaCl}$ pada saat penyerapan. Proses penggunaan ATP dalam rangka transport tergantung pada kerja enzim arginine kinase. Kepiting yang berpindah dari salinitas yang tinggi ke salinitas rendah, akan menyebabkan aktifitas enzim arginine kinase bertambah kelipatan dua dalam insang. 
Secara keseluruhan pada tahap crab muda kerja osmotic rajungan lebih baik dibandingkan pada tahap zoea ataupun megalopa. Penyebab dari hal tersebut karena pada tahap crab muda telah mengalami fase perkembangan lebih lanjut dibandingkan pada tahap zoea ataupun megalopa sehingga metamorphosis organnya lebih sempurna dan mampu melakukan kinerja osmotik lebih baik dibanding tahan sebelumnya.

Berdasarkan penelitian ini didapatkan hasil bahwa $\mathrm{pH}$ air pada pemeliharaan rajungan (P. pelagicus) pada stadia crab muda ini berkisar 7,7 sampai 8,5 . Hal ini memperlihatkan bahwa kondisi $\mathrm{pH}$ perairan tempat pemeliharaan telah sesuai dan mendukung kehidupan rajungan (P. pelagicus) tersebut. Menurut Boyd (1990), menyatakan bahwa $\mathrm{pH}$ adalah logaritma negative dari kadar ion hydrogen $(\mathrm{H}+)$ dan merupakan indicator keasaman serta kebasaan air. Berdasarkan hasil yang didapat pada setiap perlakuan masih berada pada kondisi layak yang optimum bagi media pemeliharaan rajungan ( $P$. pelagicus). Hal ini didukung oleh Astuti (2008), yang menyatakan bahwa nilai $\mathrm{pH}$ untuk pemeliharaan rajungan (P. pelagicus) pada umumnya berkisar antara 7,2 sampai 8,6 namun bila $\mathrm{pH}$ pada kisaran
7,0 sampai 8,6 masih berada dalam batas toleransi bagi kehidupan rajungan.

Berdasarkan penelitian ini didapatkan hasil bahwa oksigen terlarut (DO) air pada pemeliharaan rajungan ( $\mathrm{P}$. pelagicus) pada stadia crab muda ini berkisar 4,1 ppm sampai 5,6 ppm. Hal ini memperlihatkan bahwa kadar oksigen terlarut (DO) perairan tempat pemeliharaan berada pada kondisi layak dan mendukung kehidupan rajungan (P. pelagicus) tersebut. Hal ini didukung oleh BBPBAP (2003) dalam Astuti (2008), yang menyatakan bahwa oksigen terlarut (DO) di dalam perairan dibutuhkan untuk respirasi hewan air agar hidup serta tumbuh dengan normal. Selanjutnya, dapat dikatakan bahwa rajungan (P. pelagicus) membutuhkan oksigen terlarut (DO)berkisar antara 4,0 ppm sampai 6,0 ppm.

Kadar amoniak pada media pemeliharaan selama penelitian berlangsung 0,076-0,097 mg/L. Kadar amoniak tersebut masih layak dalam penelitian ini karena menurut Serang (2006), secara umum konsentrasi amonia dalam air tidak boleh lebih dari $1 \mathrm{mg} / 1$. Konsentrasi amonia sebesar $0.4-2 \mathrm{mg} / 1$ dalam waktu yang singkat dapat menyebabkan kematian pada ikan. Tingkat 
toksisitas amonia dipengaruhi oleh $\mathrm{pH}$ dan temperatur lingkungan perairan, dimana konsentrasi amonia meningkat dengan meningkatnya $\mathrm{pH}$ dan temperatur. Lingkungan yang mempunyai konsentrasi amonia tinggi dapat menyebabkan ikan stres, menghambat pertumbuhan dan dapat menyebabkan kematian ikan.

\section{KESIMPULAN DAN SARAN}

\section{Kesimpulan}

Adapun kesimpulan yang dapat diberikan berdasarkan hasil penelitian ini adalah sebagai berikut:

1. Perlakuan salinitas yang berbeda berpengaruh nyata terhadap tingkat kelulushidupan rajungan $\quad(P$. pelagicus), bobot mutlak dan laju pertumbuhan relatif pada stadia crab muda.

2. Media kultur yang bersalinitas $30 \mathrm{ppt}$ memberikan pengaruh terbaik dengan hasil SR terbaik sebesar 83,33 $\pm 5,77 \%$, bobot mutlak sebesar $81,87 \pm 2,42$ gram, dan nilai laju pertumbuhan relatif

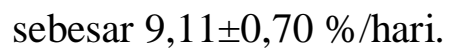

\section{Saran}

Adapun saran yang dapat diberikan dari penelitian ini adalah sebagai berikut:

1. Salinitas yang optimal sesuai kesimpulan dengan indikator kualitas air lainnya dapat dipertahankan pada kisaran yang sesuai kebutuhan rajungan (Portunus pelagicus) maka dapat di aplikasikan untuk budidaya pembesaran di tambak.

2. Disarankan melakukan penelitian lanjutan mengenai pengaruh salinitas dengan nilai yang lebih tinggi untuk mengetahui salinitas paling baik pada stadia crab.

\section{UCAPAN TERIMA KASIH}

Terima kasih penulis ucapkan kepada orang tua dan dosen pembimbing yang telah memberikan doa, dukungan dan finansial, terimakasih kepada bapak Ghofur yang telah membantu dalam proses penelitian, serta teman - teman dan semua pihak yang telah mendukung saya untuk dapat melakukan penelitian dan membantu kelancaran dalam penelitian ini.

\section{DAFTAR PUSTAKA}

Adi, Y. S. 2011. Sintasan Larva Rajungan (Portunus pelagicus) Stadia Zoea pada Berbagai Frekuensi Pemberian Pakan Alami Jenis Brachionus plicatilis. Skripsi.Fakultas Pertanian, Universitas Muhammadiyah, Makassar. 46 hal.

Anggoro, S. 2000. Pola Regulasi Osmotikdan Kerja EnzimNa-KATP Udang Windu (Penaeus monodon) pada Berbagai Fasi Molting. Aquaculture Indonesia, 1(2):15-20. 
Astuti, O. 2008. Pengaruh Salinitas Terhadap Perkembangan dan Kelangsungan Hidup Larva Menjadi Megalopa Rajungan (Portunus pelagicus). [Skripsi]. Pasca Sarjana Institut Pertanian Bogor. Bogor.

Effendie, M. I. 1997. Biologi Perikanan. Yayasan Pustaka Nusantara. Yogyakarta. $163 \mathrm{hlm}$

Effendi. 2002. Biologi Perikanan. Cetakan Kedua. Yayasan Pustaka Nusantara, Yogyakarta, $163 \mathrm{hlm}$.

Erlinda,S., L. Sara, N. Irawati. 2015. Makanan Rajungan (Portunus pelagicus) di Perairan Lakara Kabupaten Konawe Selatan, Sulawesi Tenggara. Jurnal Manajemen Sumber Daya Perairan, 1(1): 29-38

Fatmawati. 2009. Kelimpahan Relatif dan Struktur Ukuran Rajungan Di Daerah Mangrove Kecamatan Tekolabbua Kabupaten Pangkep. [Skripsi]. Jurusan Perikanan Fakultas Ilmu Kelautan dan Perikanan Universitas Hasanuddin. Makassar.

Fujaya, Y., D. D Trijuno, dan Hasnidar. 2013. Pengaruh Siklus Bulan Terhadap Dinamika Hormon Ecdysteroid Kaitannya dengan Aktivitas Molting Kepiting Bakau (Scylla olivacea) pada Budidaya Kepiting Cangkang Lunak.

Hamzah M. 2002. Pertumbuhan juvenil udang galah (Macrobachium rossenbergii) pada berbagai tingkat salinitas media [tesis]. Bogor: Program Pascasarjana, IPB.
Jafar, L. 2011. Perikanan Rajungan Di Desa Mattiro Bombang (Pulau Salemo, Sabangko dan Sagara Kabupaten Pangkep). [Skripsi]. Jurusan Perikanan Fakultas Ilmu Kelautan dan Perikanan Universitas Hasanudin. Makasar.

Lantu, S. 2010. Osmoregulasi pada Hewan Akuatik. Jurnal Perikanan dan Kelautan. Vol 4 (1): 46-50.

Oniam, V dan W. Arkronat. 2013. Development of Crab Farming The Complate Cycle of Blue Swimming Crab Culture Program (CBSC) in Thailand. Kasetsart University Fisheries Research Bulletin. 37(2): 31-43.

Serang, A. M. 2006. Pengaruh Kadar Protein dan Rasio Energi Protein Pakan Berbeda terhadap Kinerja Pertumbuhan Benih Rajungan (Portunuspelagicus). [TESIS]. Institut Pertanian Bogor.

Srigandono, B. 1981. Rancangan Percobaan Experimental Design. Universitas Diponegoo. Semarang, $140 \mathrm{hlm}$.

Pasisingi, N. 2011. Model Produksi Surplus untuk Pengelolaan Sumberdaya Rajungan (Portunus Pelagicus) Di Teluk Banten Kabupaten Serang Provinsi Bant. [Skripsi]. Departemen Manajemen Sumberdaya Perairan. Fakultas Perikanan Dan Ilmu Kelautan, Institut Pertanian Bogor.

Susanto B. 2007. Pertumbuhan, Sintasan, dan Keragaman Zoea Sampai Megalpoa Rajungan (Purtunus pelagicus) Melalui Penurunan 
Salinitas. Jurnal Perikanan. 9 (1): 154-160.

Susanto, S., Nurhadi dan A. Leusi. 2014. Kepadatan Populasi Kepiting Rajungan (Portunus pelagicus L.) Di Teluk Buo Kecamatan Bungus Teluk Kabung Padang Sumatera Barat. Artikel. Hlm 1-5.

Takeuchi, T. 1988. Laboratory WorkChemical Evaluation of Dietary Nutriants. In: Watanabe, T. (Ed.). Fish Nutrition and Mariculture. JICA, Tokyo University Fish. Pp. 179-229.

Taqwa, F. H., Ade, D. S dan Karim, G. 2012. Kelangsungan Hidup, Kerja Osmotik dan Konsumsi Oksigen Pasca Larva Udang Galah Selama Penurunan Salinitas dengan Air Rawa Pengencer Yang Ditambahkan Kalium. Prosiding InSINas. 98-102. Wahyu, P. 2012. Aktivitas Osmoregulasi, Respons Pertumbuhan, dan Energetic Cost pada Ikan yang dipelihara dalam Lingkungan Bersalinitas. Jurnal Akuakultur. 7(1): 44-51.

Widodo dan Suadi. 2006. Pengelolaan Sumberdaya Perikanan Laut. Yogyakarta.

Yasin, H. 2011. Pengaruh Pemberian Berbagai Kadar Karbohidrat dan Lemak Pakan Ber-Vitomolt terhadap Efisiensi Pakan dan Pertumbuhan Kepiting Bakau (Scylla sp). Fakultas Ilmu Kelautan dan Perikanan Universitas Hasanuddin, Makassar 32: 1-7.
Zaidin, M. Z., Irwan. J. E dan Kadir S. 2013. Sintasan Larva Rajungan (Portunus pelagicus) Stadia Megalopa Melalui Kombinasi Artemia dan Branchionus plicatilis. Jurnal Mina Laut Indonesia. 1(1):112-121. 